\title{
Uptake of 3,3',5,5'-Tetraiodothyroacetic Acid and 3,3',5'- Triiodothyronine in Cultured Rat Anterior Pituitary Cells and Their Effects on Thyrotropin Secretion*
}

\author{
MARIA E. EVERTS $\dagger$, THEO J. VISSER, ELLIS P. C. M. MOERINGS, \\ ANITA M. P. TEMPELAARS, HANS VAN TOOR, ROELOF DOCTER, \\ MARION DE JONG, ERIC P. KRENNING, AND GEORG HENNEMANN \\ Departments of Internal and Nuclear Medicine, Erasmus University Medical School, $3000 \mathrm{DR}$ \\ Rotterdam, The Netherlands
}

\begin{abstract}
We compared the uptake, metabolism, and biological effects of tetraiodothyroacetic acid (Tetrac) and $r \mathrm{~T}_{3}$ in anterior pituitary cells with those of $\mathrm{T}_{4}$ and $\mathrm{T}_{3}$. Cells were isolated from adult male Wistar rats and cultured for 3 days in medium with $10 \%$ fetal calf serum. Uptake was measured at $37 \mathrm{C}$ in medium with $0.1 \%$ BSA for ${ }^{125}$ I]Tetrac $(200,000 \mathrm{cpm} ; 240 \mathrm{pM})$ and $\left[{ }^{125} \mathrm{I}\right] \mathrm{T}_{4}(100,000 \mathrm{cpm} ; 175 \mathrm{pM})$ or with $0.5 \%$ BSA for [ $\left.{ }^{125} \mathrm{I}\right] \mathrm{r} \mathrm{T}_{3}(100,000 \mathrm{cpm} ; 250 \mathrm{pM})$ and $\left[^{125} \mathrm{I}\right] \mathrm{T}_{3}(50,000 \mathrm{cpm}$; $50 \mathrm{pm}$ ). The free fraction of Tetrac was $1 \%$ that of $\mathrm{T}_{4}$ (in medium with 0.1 and with $0.5 \%$ BSA), and the free fraction of $r \mathrm{~T}_{3}$ was half that of $\mathrm{T}_{3}$. Uptake of the four tracers increased sharply up to $1 \mathrm{~h}$ of incubation and then leveled off. Expressed as femtomoles per pM free hormone, uptake at equilibrium was $1.16 \pm 0.16(\mathrm{n}=6)$ for Tetrac, $0.15 \pm 0.01$ $(n=6)$ for $T_{4}, 0.023 \pm 0.003(n=6)$ for $r T_{3}$, and $0.21+0.02(n=6)$ for $\mathrm{T}_{3}$. Cell-associated radioactivity after incubation for $24 \mathrm{~h}$ with
\end{abstract}

$\left[{ }^{125} \mathrm{I}\right]$ Tetrac was represented for $15 \%$ by $\left[{ }^{125} \mathrm{I}\right]$ Triac; after incubation with $\left[{ }^{125} \mathrm{I}\right] \mathrm{T}_{4}$ for $15-20 \%$ by $\left[{ }^{125} \mathrm{I}\right] \mathrm{T}_{3}$, after incubation with [ $\left.{ }^{125} \mathrm{I}\right] \mathrm{r}_{3}$ for $6 \%$ by $\left[{ }^{125} \mathrm{I}\right] 3,3^{\prime}-\mathrm{T}_{2}$, while $\left[{ }^{125} \mathrm{I}\right] \mathrm{T}_{3}$ was still for $98 \%\left[{ }^{125} \mathrm{I}\right] \mathrm{T}_{3}$. Exposure of cells for $2 \mathrm{~h}$ to $100 \mathrm{nM}$ TRH stimulated TSH release by $90-135 \%$. Tetrac was effective in reducing this response at a free concentration of $0.05 \mathrm{pm}$, but $\mathrm{rT}_{3}$ was effective only at a free concentration of $16 \mathrm{nM}$. A free Tetrac concentration of $5 \mathrm{pm}$ was equally effective as $50 \mathrm{pm}$ free $\mathrm{T}_{4}$ in reducing the $\mathrm{TSH}$ response to $\mathrm{TRH}$. In human serum, Tetrac was exclusively bound to $\mathrm{T}_{4}$-binding prealbumin. The free Tetrac fraction was $0.001 \%$ in control subjects and rose 2 - to 12 -fold in patients with nonthyroidal illness. As uptake of $\left[{ }^{125} \mathrm{I}\right]$ Tetrac in the pituitary was higher than that of $\mathrm{T}_{4}$ and $\mathrm{T}_{3}$, and it was more potent than $\mathrm{T}_{4}$ in reducing TSH release, Tetrac may be of potential significance for the regulation of TSH secretion in vivo. (Endocrinology 136: 4454-4461, 1995)
$\mathrm{N}^{\mathrm{o}}$

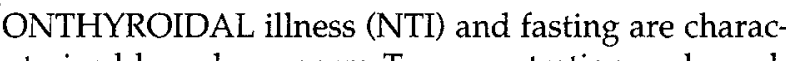
terized by a low serum $\mathrm{T}_{3}$ concentration and an elevated serum concentration of $r T_{3}$, whereas the serum $T_{4}$ concentration is normal or eventually decreased (1-4). In the face of the low serum $T_{3}$ and $T_{4}$ concentrations, the serum TSH level is inappropriately low $(1,2,4,5)$.

Recently, it was proposed that changes in $\mathrm{T}_{4}$ metabolism during fasting and NTI, i.e. a shift from deiodination to increased conjugation or alanine side-chain alteration, may result in metabolites with a TSH-suppressing effect. The first to be evaluated was $T_{3}$ sulfate (6), but this metabolite appeared to be biologically inactive at the pituitary level $(7,8)$, perhaps because it does not enter the tissue (8). The second to be tested was the acetic acid derivative of $\mathrm{T}_{3}$, triiodothyroacetic acid (Triac) $(9,10)$, which is rapidly taken up by the pituitary (11) and has a profound TSH-suppressing effect both in vitro $(11,12)$ and in vivo $(13,14)$. Like Triac, the acetic acid derivative of $T_{4}$, tetraiodothyroacetic acid (Tetrac), was suggested to contribute to the suppression of TSH secretion

Received May 1, 1995

Address all correspondence and requests for reprints to: Maria E. Everts, Ph.D., Depariment of Internal Medicine III, Erasmus University Medical School, Room Bd 240, Postbox 1738, 3000 DR Rotterdam, The Netherlands.

* This work was supported by the Trustfonds of Erasmus University Rotterdam, The Netherlands.

t Recipient of a fellowship from the Royal Netherlands Academy of Arts and Sciences. during fasting and NTI (10). Administration of Tetrac reduced the TSH response to TRH in euthyroid subjects (13). Furthermore, in fasting subjects, the serum Tetrac concentration was reported to increase 2-fold (15).

Although $\mathrm{rT}_{3}$ is not ascribed any biological activity, recent studies indicate that one of its metabolites 3,3'-diiodothyronine $\left(3,3^{\prime}-\mathrm{T}_{2}\right)$ stimulates the mitochondrial respiratory rate (16). A similar action has been reported for 3,5- $\mathrm{T}_{2}$ (a product of $\mathrm{T}_{3}$ deiodination) $(16,17)$, which, in addition, has been shown to suppress TSH secretion in rats (18). The pituitary contains the enzyme that deiodinates $\mathrm{rT}_{3}(19)$, but before this can occur, $\mathrm{rT}_{3}$ has to enter the pituitary cells.

The present study was undertaken to investigate 1) the uptake and metabolism of ${ }^{125} \mathrm{I}_{\text {-labeled }} \mathrm{rT}_{3}$ and Tetrac in cultured anterior pituitary cells compared to that of ${ }^{125}$ I-labeled $\mathrm{T}_{3}$ and $\mathrm{T}_{4} ; 2$ ) the effects of unlabeled Tetrac and $\mathrm{rT}_{3}$ on the uptake of $\left[{ }^{125} \mathrm{I}^{\mathrm{T}} \mathrm{T}_{3}\right.$; and 3) the effects of unlabeled Tetrac, $\mathrm{rT}_{3}$, $3,3^{\prime}-\mathrm{T}_{2}$, and $3,5-\mathrm{T}_{2}$ on TRH-induced TSH release. Finally, we evaluated the distribution of Triac and Tetrac among serum proteins as well as the free fraction of Triac and Tetrac in serum of control subjects and NTI patients.

\section{Materials and Methods}

\section{Materials}

All solutions used for cell isolation and cell culture were obtained from GIBCO Europe (Breda, The Netherlands), with the exception of human serum albumin (Central Laboratory of the Red Cross Blood 
Transfusion Service, Amsterdam, The Netherlands), dispase (grade II; Buehringer Mannheim, Mannheim, Germany), and fungizone (BristolMyers Squibb, Woerden, The Netherlands). Culture dishes (48 wells) were obtained from Costar (Cambridge, MA). TRH was obtained from Hoechst (Frankfurt am Main, Germany). All iodothyronines, 3,5-diiodothyroacetic acid (3,5-Diac), Triac, and Tetrac, were obtained from Henning Berlin (Berlin, Germany). Piperazine- $N, N^{\prime}$-bis-[2-ethane sulfonic acid] (PIPES), HEPES, $N$, N-bis-[2-hydroxyethyl]2-aminoethane sulfonic acid (Bes), 6-propyl-2-thiouracil (PTU), and BSA (fraction V) were obtained from Sigma Chemical Co. (St. Louis, MO). $\left[3^{\prime}, 5^{\prime}-{ }^{125} \mathrm{I}\right] \mathrm{T}_{4}(1500$ $\mu \mathrm{Ci} / \mu \mathrm{g}),\left[3^{\prime}-{ }^{125} \mathrm{I}\right] \mathrm{T}_{3}(3070 \mu \mathrm{Ci} / \mu \mathrm{g}),\left[3^{\prime}, 5^{\prime}-{ }^{125} \mathrm{I}\right] \mathrm{rT} \mathrm{T}_{3}(1200 \mu \mathrm{Ci} / \mu \mathrm{g})$, and carrier-free $\mathrm{Na}^{125}$ I were purchased from Amersham International (Aylesbury, UK). HPLC pure $\left.\left[3^{\prime}-{ }^{125} \mathrm{I}\right] \mathrm{Triac}\right)(2730 \mu \mathrm{Ci} / \mu \mathrm{g})$ and $\left[3^{\prime}, 5^{\prime}-\right.$ ${ }^{125} \mathrm{I}$ Tetrac $(2200 \mu \mathrm{Ci} / \mu \mathrm{g})$ were prepared from $\mathrm{Na}^{125} \mathrm{I}$ and 3,5-Diac or Triac, respectively, using the chloramine-T method followed by purification on Sephadex LH-20 (20). Sephadex LH H-20 and G-25 were obtained from Pharmacia (Uppsala, Sweden). All other reagents were of the highest purity available.

\section{Animals}

All experiments were performed using male Wistar rats, weighing $220-250 \mathrm{~g}$. The animals had free access to food and water and were kept in a controlled enviromment $(21 \mathrm{C})$ with constant day length $(12 \mathrm{~h})$.

\section{Cell culture}

Animals (12-18 for each experiment) were killed between 0900-0930 $h$ by decapitation. The pituitary glands were removed within 5 min, the neurointermediate lobe was discarded, and the anterior lobes were collected in calcium- and magnesium-free Hanks ${ }^{r}$ Balanced Salt Solution supplemented with $10 \mathrm{~g}$ /liter humban serum albumin, pericillin $\left(10^{5}\right.$ $\mathrm{U} /$ liter), fungizone $(0.5 \mathrm{mg}$ /liter), and sodium bicarbonate $(0.4 \mathrm{~g} /$ liter $)$. Anterior pituitary cells were dissociated with dispase (final concentration, $2.4 \times 10^{3} \mathrm{U} /$ liter) for $2 \mathrm{~h}$ at $37 \mathrm{C}$ in a shaking incubator. From each pituitary, around $1.5 \times 10^{6}$ cells were obtained, and the viability of the cells, as determined by trypan blue exclusion, was greater than $90 \%$.

The cells were cultured at $37 \mathrm{C}$ in a water-jacketed incubator with $5 \%$ $\mathrm{CO}_{2}$ at a density of 500,000 cells/well in 48-well culture dishes. The cells had attached to the wells after 2 days of culture. On day 3 , the cells were used for experiments. The culture medium consisted of Minimal Essential Medium with Earle's salts supplemented with nonessential amino acids, sodium pyruvate ( $1 \mathrm{mmol} / \mathrm{liter}), 10 \%$ fetal calf serum, penicillin $\left(10^{5} \mathrm{U} /\right.$ liter $)$, fungizone $(0.5 \mathrm{mg} /$ liter $)$, L-glutamine $(2 \mathrm{mmol} /$ liter), and sodium bicarbonate (2.2 g/liter), pH 7.4 (21-23).

\section{Cellular uptake of ${ }^{125}$ I-labeled $r T_{3}, T_{3}$, Tetrac, and $T_{4}$}

After removal of the culture medium, cells were preincubated with $0.5 \mathrm{ml}$ incubation medium for $30 \mathrm{~min}$ at $37 \mathrm{C}$. The incubation medium was identical to the culture medium, except that fetal calf serum was replaced by $0.5 \%, 0.1 \%$, or $0.01 \%$ BSA. After preincubation the medium was removed, and incubation ( $15 \mathrm{~min}-4 \mathrm{~h}$ ) was started with $0.25 \mathrm{ml}$ medium containing [ $\left.{ }^{125} \mathrm{~T}\right] \mathrm{rT}_{3}(100,000 \mathrm{cpm} ; 250 \mathrm{pM}),\left[^{125} \mathrm{~T}\right] \mathrm{T}_{3}(50,000 \mathrm{cpm}$; $50 \mathrm{pM}), \mathrm{I}^{125} \mathrm{IIT}_{4}(100,000 \mathrm{cpm} ; 175 \mathrm{pm})$, or [ $\left.{ }^{125} \mathrm{I}\right]$ Tetrac $(200,000 \mathrm{cpm} ; 240$ $\mathrm{pm})$. Incubations lasting for more than $1 \mathrm{~h}$ were performed at $37 \mathrm{C}$ in humiditied air with $5 \% \mathrm{CO}_{2}$. Incubations of shorter duration took place in a $37 \mathrm{C}$ incubation chamber on a rotating device without $\mathrm{CO}_{2}$. Therefore, the $\mathrm{NaHCO}_{3}$ in the culture medium was replaced by an equimolar amount of HEPES ( $8.9 \mathrm{~mm})$, PIPES (10.6 mM), and Bes (11.2 mM). After incubation, the medium was removed, and cells were washed with $1-\mathrm{ml}$ volumes of ice-cold saline to remove tracer not bound to the cells. Cells were dissolved in $1 \mathrm{ml} 0.1 \mathrm{~N} \mathrm{NaOH}$ and counted for ${ }^{125} \mathrm{I}$ activity in a 16-channel $\gamma$-counter (NE 1600, Nuclear Enterprises, Edinburgh, Scotland). The amount of ${ }^{125}$ I-labeled compound taken up was expressed as a percentage of the radioactivity added (percent dose). The same procedure was applied to the incubations without cells. All results are corrected for the amount of radioactivity retained in the wells without cells.

For HPLC analysis of metabolites, incubations were performed for 24 $\mathrm{h}$ with $2 \times 10^{6} \mathrm{cpm} \mathrm{T} \mathrm{T}_{3}(2 \mathrm{nM}), \mathrm{T}_{4}(3.5 \mathrm{nM}), \mathrm{rT}_{3}(5 \mathrm{nM})$, or Tetrac (2.4 nM). Cells were further processed as described above.

\section{LH-20 chromatography}

Aliquots of the incubation medium and cell extracts were chromatographed on Sephadex LH-20 (24). Iodide was eluted from the column with $4 \times 1 \mathrm{ml} 0.1 \mathrm{~N} \mathrm{HCl}$. Subsequently, conjugates were eluted with $8 \times$ $1 \mathrm{ml} \mathrm{H}_{2} \mathrm{O}$, and finally, iodothyronines were removed from the column with $3 \times 1 \mathrm{ml} 1 \% \mathrm{NH}_{4} \mathrm{OH}$ in ethanol.

\section{HPLC}

The solvent $\left(1 \% \mathrm{NH}_{4} \mathrm{OH}\right.$ in ethanol) of samples prepurified on Sephadex LH-20 was evaporated under a stream of $\mathrm{N}_{2}$ at $50 \mathrm{C}$. The residue was redissolved in the HPLC mobile phase and injected onto Chromspher $\mathrm{C}_{18}$ columns $(10 \times 0.3 \mathrm{~cm}$; Chrompack International, Middelburg, The Netherlands) fitted in a Waters HPLC system (Waters Associates, Milford, MA). Isocratic elution was performed with a 53:47 mixture of methanol in $0.02 \mathrm{M}$ ammonium acetate $(\mathrm{pH} 4)$ at a flow rate of $0.9 \mathrm{ml} / \mathrm{min}$ for studies of ${ }^{125}{ }^{12}\left[\mathrm{~T}_{4}\right.$ metabolism and with a $60: 40$ mixture of the same solutions at the same flow rate for studies of [ $\left.{ }^{125} \mathrm{I}\right]$ Tetrac metabolism. The latter was performed to speed up elution of the acetic acid derivatives. Fractions of $0.3 \mathrm{~min}$ were collected and counted for radioactivity. The retention times of the four unlabeled reference compounds were determined with the two elution mixtures by monitoring the absorbance of the eluate at $254 \mathrm{~nm}(20)$. The procedure was applied to cell samples as well as to the blank samples (without cells) to allow correction for degradation of $\left[{ }^{125} \mathrm{I}\right] \mathrm{T}_{4}$ or $\left[{ }^{125} \mathrm{I}\right] \mathrm{Tetrac}$ during evaporation and HPLC analysis.

\section{TSH release}

After removal of culture medium, cells were washed once with incubation medium. The incubation medium was identical to the culture medium, except that the fetal calf serum was replaced by $0.5 \%$ BSA. Pituitary cells were preincubated $(0.5 \mathrm{ml})$ for $2 \mathrm{~h}$ at $37 \mathrm{C}$ in a waterjacketed incubator with $5 \% \mathrm{CO}_{2}$ in the absence or presence of variable concentrations $(0.01 \mathrm{nM}$ to $1 \mu \mathrm{M})$ of $\mathrm{T}_{3}, \mathrm{~T}_{4}, \mathrm{rT}_{3}$, Triac, Tetrac, $3,5-\mathrm{T}_{2}$, or $3,3^{\prime}-\mathrm{T}_{2}$. The preincubation medium was discarded, and fresh incubation medium $(0.5 \mathrm{ml})$ was added containing TRH $(100 \mathrm{nM})$ without or with the same additions as described above. Incubation was continued for 2 $\mathrm{h}$ at $37 \mathrm{C}$. This medium was removed, centrifuged $(2000 \times \mathrm{g})$, and stored at $-20 \mathrm{C}$. TSH in incubation medium was measured by RIA (22).

\section{Free fractions of iodothyronine derivatives}

The free fractions of iodothyronines, Tetrac and Triac, were determined by equilibrium dialysis (25). The free Triac fraction was corrected for the fact that around $70 \%$ of $\left[{ }^{125} \mathrm{I}\right]$ Triac precipitated with $\mathrm{MgCl}_{2}$. The free fractions of all iodothyronines used in this study were determined in incubation medium with $0.5 \% \mathrm{BSA}$; those of Tetrac and $\mathrm{T}_{4}$ were also determined in incubation medium with $0.1 \% \mathrm{BSA}$. The free fractions of Triac and Tetrac were also determined in the serum of five control subjects and six NTI patients.

\section{Agar gel electrophoresis}

The distribution of Triac and Tetrac among serum binding proteins was determined by agar gel electrophoresis (26). The sera $(50 \mu 1)$ were mixed with bromophenol blue $(1 \mu \mathrm{l})$ and ${ }^{125} \mathrm{I}$-labeled Triac or Tetrac $\left(10^{6}\right.$ $\mathrm{cpm})$. Gels were run for $60 \mathrm{~min}$ at $70 \mathrm{~mA} /$ slide $(-150 \mathrm{~V})$ at $15 \mathrm{C}$. Successive slices of $2 \mathrm{~mm}$ gel were counted, and the binding proteins $\mathrm{T}_{4}$-binding globulin (TBG), albumin, and $\mathrm{T}_{4}$-binding prealbumin (TBPA) were identified using the bromophenol blue staining of albumin as a reference; the region between the origin and albumin contained TBG, whereas the region anodal to albumin contained TBPA.

\section{Statistics}

The statistical significance of any of the tested compounds on $\left[{ }^{125} \mathrm{I}\right] \mathrm{T}_{3}$ uptake or on TSH secretion was evaluated by Student's $t$ test or one-way analysis of variance and Duncan's test for multiple comparisons. $P<$ 0.05 was regarded as statistically significant. 


\section{Results}

\section{Free fractions of iodothyronine derivatives}

The free fractions of 3,3'- $T_{2}, T_{3}, \mathrm{rT}_{3}, \mathrm{~T}_{4}$, Triac, and Tetrac in medium with $0.5 \%$ BSA are shown in Fig. 1. The free fraction decreases as the number of iodine atoms in the compound increases, whereas a change in the alanine sidechain to acetic acid, as in Triac and Tetrac, decreases the free fraction by a factor 8 (Triac $v s . \mathrm{T}_{3}$ ) or 100 (Tetrac vs. $\mathrm{T}_{4}$ ). The free fractions of Tetrac and $\mathrm{T}_{4}$ in medium with $0.1 \% \mathrm{BSA}$ amounted to $0.029 \pm 0.001 \%(\mathrm{n}=3)$ and $3.33 \pm 0.08 \%(\mathrm{n}=$ 4), respectively, i.e. again a 100-fold difference. The free $\mathrm{T}_{3}$ fraction $(3.61 \pm 0.05 \% ; n=12)$ did not change after the addition of $1 \mathrm{nM}-1 \mu \mathrm{M} \mathrm{T}$, Triac, Tetrac, or $\mathrm{rT}_{3}$, but it increased to $4.53 \pm 0.13 \%(n=4), 4.51 \%(n=2), 4.17 \pm 0.02 \%(n=4)$, and $4.43 \pm 0.09 \%(\mathrm{n}=4)$ after the addition of $10 \mu \mathrm{M} \mathrm{T} \mathrm{T}_{3}$, Triac, Tetrac and $\mathrm{rT}_{3}$, respectively.

\section{Time course of uptake of $\left[{ }^{125} I\right] r T_{3}$ and $\left.{ }^{125} I\right] T e t r a c$}

Figure 2 shows the time course of $\left[{ }^{125} \mathrm{I}\right] \mathrm{r} \mathrm{T}_{3}$ uptake compared with that of $\left[{ }^{125} \mathrm{I}\right] \mathrm{T}_{3}$ expressed as a percentage of the dose (Fig, 2A) or as femtomoles per pM free hormone (Fig. 2B). The uptake curve for $\left.{ }^{[25}{ }^{12}\right] \mathrm{T}_{3}$ was similar to that previuusly described $(11,22)$, showed a steep phase up to 1 ho incubation, and reached equilibrium between 1-4 $\mathrm{h}$ of incubation (Fig. 2A). At any time point of the experiment, the uptake of $\left[{ }^{125} \mathrm{I}\right] \mathrm{rT}_{3}$ was only $3-4 \%$ of the uptake of $\left[{ }^{125} \mathrm{I}\right] \mathrm{T}_{3}$ (Fig. 2A, lower curve). When expressed as femtomoles per pM free hormone, there was still a large difference between the uptake of the two hormones, but as the free fraction of $\mathrm{rT}_{3}$ was half that of $\mathrm{T}_{3}$, the values for $\mathrm{rT}_{3}$ uptake were about $10 \%$ of those for $\mathrm{T}_{3}$ uptake (Fig. 2B).

Similar comparisons were made for the uptake of $\left[{ }^{125} \mathrm{I}\right] \mathrm{Tet}-$ rac and $\left[{ }^{125} \mathrm{IT}_{4}\right.$ in incubation medium with $0.1 \%$ BSA (Fig. 3). Uptake of ${ }^{125} \mathrm{IlT}_{4}$ showed a steep phase up to $1 \mathrm{~h}$ of incubation and reached a plateau at $4 \mathrm{~h}$ of incubation (Fig. 3A, upper curve). Uptake of $\left[{ }^{125} \mathrm{I}\right]$ Tetrac, expressed as percent dose, was less than $0.15 \%$ at any time point of the incubation (Fig. 3A, lower curve), and $\left[{ }^{125} \mathrm{ITT}_{4}\right.$ uptake was about 10 -fold higher at equilibrium (Fig. 3A, upper curve). I Iowever, when the data were expressed as femtomoles per pM free hormone, the picture was precisely reversed; the maximum uptake of $\left[{ }^{125} \mathrm{I}\right]$ Tetrac was $1.16 \pm 0.16(\mathrm{n}=6) \mathrm{fmol} / \mathrm{pM}$ free Tetrac, and
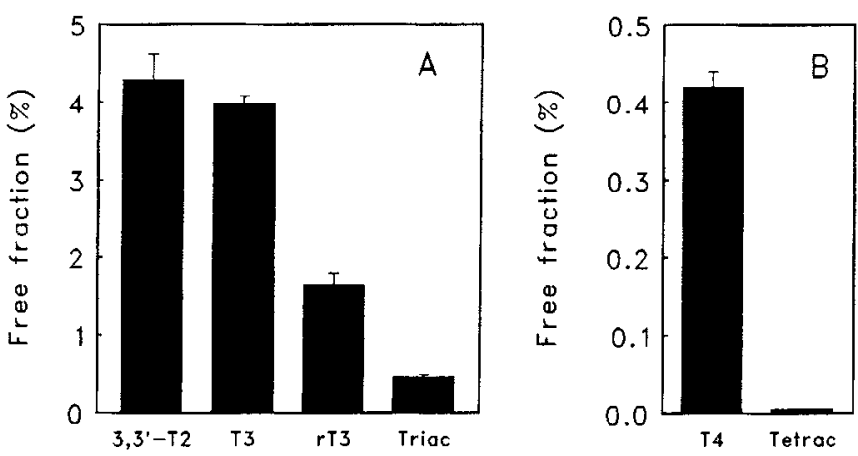

FIG. 1. Free fraction of iodothyronines and analogs in incubation medium with $0.5 \%$ BSA. Bars show the mean $\pm \mathrm{SE}$ of three to eight determinations of the free fraction by equilibrium dialysis. A and $B$ differ by a factor of 10 in the scale on the $y$-axis.
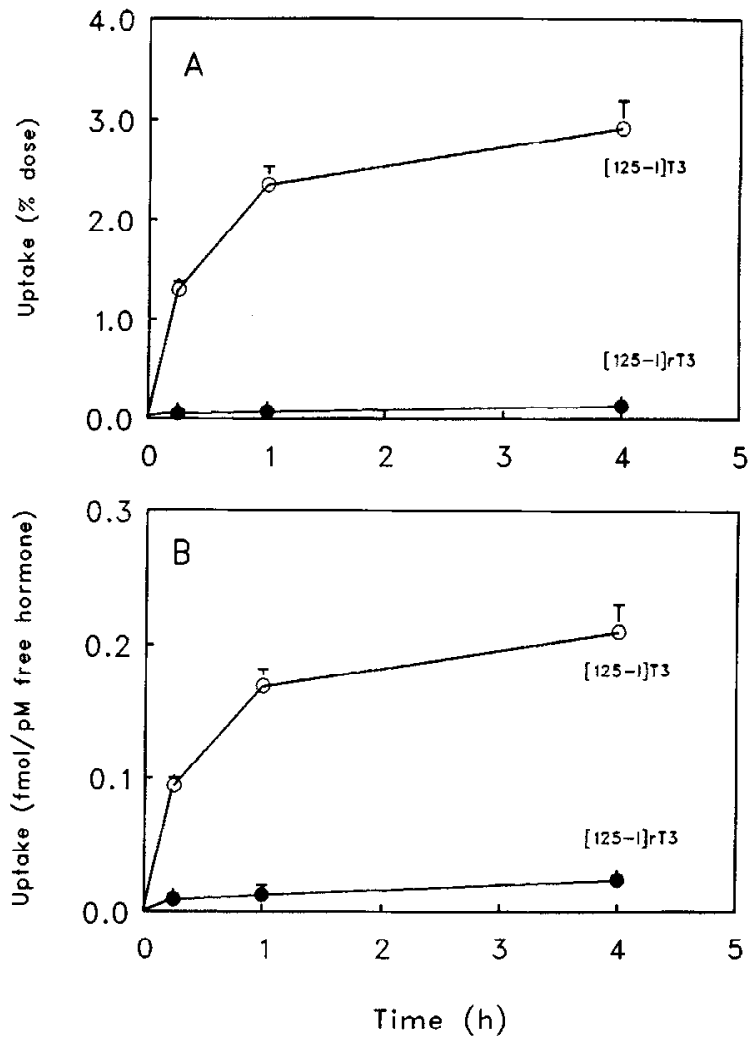

FIG. 2. Time course of uptake of $\left[{ }^{125} \mathrm{I}\right] \mathrm{T}_{3}(O)$ and $\left[{ }^{125} \mathrm{I}\right] \mathrm{r} \mathrm{T}_{3}(O)$ in cultured anterior pituitary cells expressed as the percent dose (A) or as femtomoles per pM free hormone (B). Cells were cultured for 3 days at a density of 500,000 cells/well. After preincubation for $30 \mathrm{~min}$ in incubation medium with $0.5 \% \mathrm{BSA}$, cells were incubated for $15 \mathrm{~min}$, $1 \mathrm{~h}$, or $4 \mathrm{~h}$ in the presence of $\left[{ }^{125} \mathrm{I}^{\mathrm{T}} \mathrm{T}_{3}(50,000 \mathrm{cpm})\right.$ or $\left[{ }^{125} \mathrm{I}\right] \mathrm{r} \mathrm{T}_{3}(100,000$ $\mathrm{cpm})$. Data represent the mean $\pm \mathrm{SE}$ of six observations from two independent experiments.

that of $\left[{ }^{125} \mathrm{I}\right] \mathrm{T}_{4}$ was $0.15 \pm 0.01(\mathrm{n}=6) \mathrm{fmol} / \mathrm{pM}$ free $\mathrm{T}_{4}(P<$ 0.001; Fig. 3B).

\section{Metabolism of iodothyronines and Tetrac}

Table 1 shows the presence of iodide and conjugates in the incubation medium (first two columns) and HPLC analysis of the cell-associated radioactivity (last four columns) after incubation of pituitary cells with $\left[{ }^{125} \mathrm{I}\right] \mathrm{T}_{3}, \mathrm{I}^{125} \mathrm{I}_{\mathrm{T}}$, and $\left.{ }^{125} \mathrm{I}\right] \mathrm{rT}_{3}$ for $24 \mathrm{~h}$. After incubation with $\left[{ }^{125} \mathrm{I}\right] \mathrm{T}_{3}$, no iodide was detectable with only a small amount of conjugates. Furthermore, almost all cell-associated radioactivity represented $\left[{ }^{125} \mathrm{I}\right] \mathrm{T}_{3}$, indicating that $\mathrm{T}_{3}$ is not metabolized in pituitary cells. Within the same experiment, however, $\left[{ }^{125} \mathrm{I}\right] \mathrm{T}_{4}$ was metabolized, as shown by the production of iodide in the medium and the presence of $\left[{ }^{125} \mathrm{I}\right] \mathrm{T}_{3}$ in the cells, representing $20 \%$ of the cell-associated radioactivity. The conversion of $\left[{ }^{125} \mathrm{ITT}_{4}\right.$ to $\left[{ }^{125} \mathrm{I}\right] \mathrm{T}_{3}$ was not inhibited by simultaneous incubation with $100 \mu \mathrm{M}$ PTU, but was almost completely blocked by the presence of $1 \mu \mathrm{M}$ unlabeled $\mathrm{T}_{4}$. Finally, incubation with $\left.{ }^{125} \mathrm{I}\right] \mathrm{rT}_{3}$ resulted in a significant production of iodide and conjugates, whereas about $6 \%$ of the cell-associated radioactivity represented $\left[{ }^{125} \mathrm{I}\right] \mathrm{T}_{2}$.

The 24-h uptake and metabolism of $\left[{ }^{125} \mathrm{I}\right]$ Tetrac were compared with those of $\left.{ }^{125}{ }^{12}\right] \mathrm{T}_{4}$ (Table 2). To ensure that uptake 

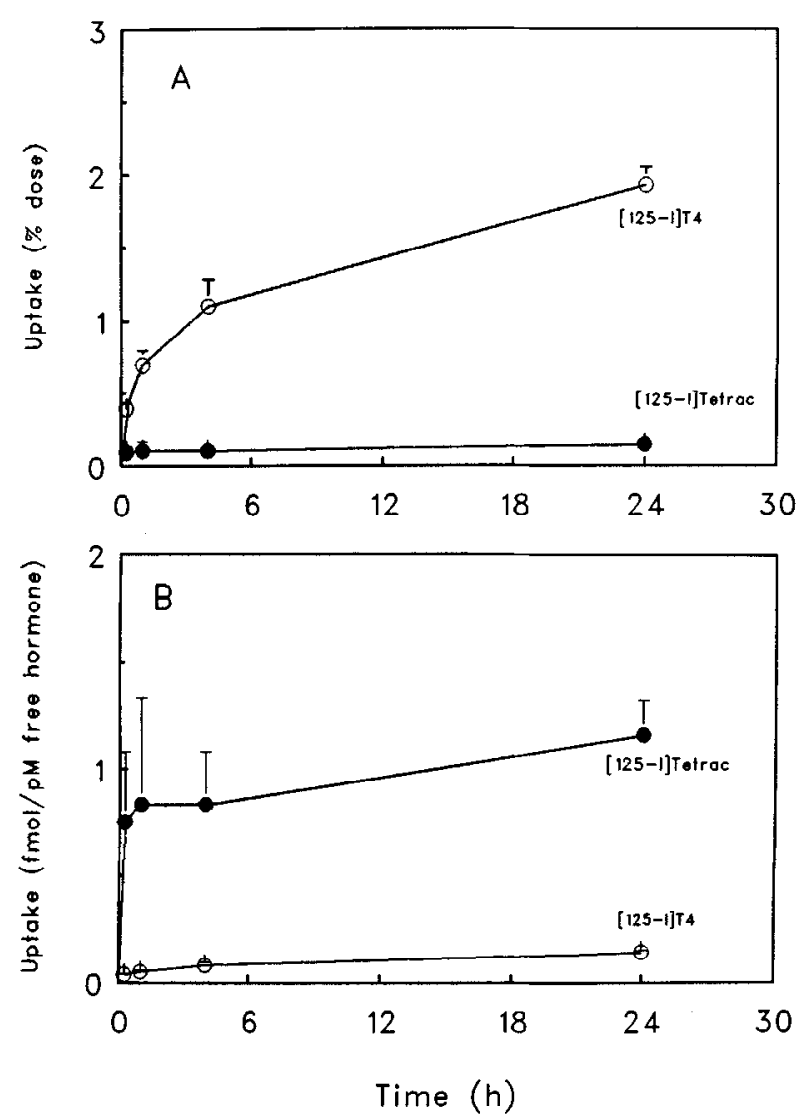

FIG. 3 Time course of uptake of $\left[{ }^{125} \mathrm{I}\right] \mathrm{T}_{4}(\mathrm{O})$ and $\left[{ }^{125} \mathrm{I}\right] \mathrm{Tetrac}(\mathrm{)})$ in cultured anterior pituitary cells expressed as the percent dose (A) or as femtomoles per pM frec hormone (B). Cells were cultured and the experiment was performed as described in Fig. 2, except that the incubation medium contained $0.1 \% \mathrm{BSA}$ and $\left[{ }^{125} \mathrm{I}\right] \mathrm{T}_{4}\left(0.1-2 \times 10^{6}\right.$ $\mathrm{cpm})$ or $\left[{ }^{125} \mathrm{I}\right]$ Tetrac $\left(0.2-2 \times 10^{6} \mathrm{cpm}\right)$. Data represent the mean $\pm \mathrm{sE}$ of six observations from two independent experiments.

of $\left[{ }^{125} \mathrm{I}\right]$ Tetrac was large enough to allow Sephadex LH-20 chromatography and HPLC, the experiment was carried out with $0.01 \%$ and $0.1 \%$ BSA in the incubation medium. As shown in Table 2 , about $15 \%$ of the cell-associated radioactivity of $\left[{ }^{125} \mathrm{I}\right] \mathrm{T}_{4}$ and $\left[{ }^{125} \mathrm{I}\right]$ Tetrac represented $\left[{ }^{125} \mathrm{I}\right] \mathrm{T}_{3}$ and $\left[{ }^{125} \mathrm{I}\right]$ Triac, respectively, after incubation for $24 \mathrm{~h}$ under the two experimental conditions. Net release of $\left.{ }^{[25} \mathrm{I}\right]$ iodide into the medium was: in $0.01 \% \mathrm{BSA}, 3.9 \%(\mathrm{n}=2)$ from $\left[{ }^{125} \mathrm{I}\right] \mathrm{T}_{4}$ and $1.8 \pm 0.2 \%(n=3)$ from $\left[{ }^{125} \mathrm{I}\right]$ Tetrac; and in $0.1 \% \mathrm{BSA}, 2.8 \pm$ $0.3 \%(\mathrm{n}=3)$ from $\left[{ }^{125} \mathrm{I}\right] \mathrm{T}_{4}$ and $0.6 \pm 0.1 \%(\mathrm{n}=3)$ from [ ${ }^{125}$ I]Tetrac.

\section{Effects of $r T_{3}$, Tetrac, and Triac on $\left[{ }^{125} I\right] T_{3}$ uptake}

Due to the very low tracer uptake (percent dose) of $\left[^{125} \mathrm{I}\right] \mathrm{T}$ etrac and $\left.\mathrm{I}^{125} \mathrm{I}\right] \mathrm{rT} \mathrm{T}_{3}$, it was impossible to perform detailed studies on the effects of thyroid hormone analogs or metabolic inhibitors on the plasma membrane uptake of these tracers. Therefore, we studied the effects of unlabeled Tetrac and Triac on the time course of $\left[{ }^{125} \mathrm{ITT}_{3}\right.$ uptake (Fig. 4) as well as the effects of unlabeled $\mathrm{rT}_{3}$ and Tetrac on the 15-min uptake of $\left.{ }^{125} \mathrm{I}\right] \mathrm{T}_{3}$ (Fig. 5).

The uptake of ${ }^{125} \mathrm{TJT}_{3}$ was at any time point significantly reduced by the presence of $10 \mu \mathrm{M}$ Tetrac or Triac, and the effects of these analogs were similar. The effects of Tetrac and Triac were approximately $35 \%, 45 \%$, and $70 \%$ after $15 \mathrm{~min}$, $1 \mathrm{~h}$, and $4 \mathrm{~h}$ of incubation, respectively (all $P<0.001$; Fig. 4).

Measurements of $\left[{ }^{125}{ }^{2}\right] \mathrm{T}_{3}$ uptake in the linear part of the curve presented in Fig. 4, i.e. after 15 min of incubation, can be used to study uptake at the level of the pituitary plasma membrane $(22,23)$. The effects of Tetrac and $\mathrm{rT}_{3}$ at concentrations from $1 \mathrm{nM}$ to $1 \mu \mathrm{M}$ on the 15 -min uptake of $\left[{ }^{125} \mathrm{I}_{3} \mathrm{~T}_{3}\right.$ were compared with those of unlabeled $T_{3}$. The effect of unlabeled $T_{3}$ increased progressively with the concentration, reaching a maximum of $68 \%$ suppression $(P<0.05)$ at $10 \mu \mathrm{M}$. In contrast, Tetrac and $\mathrm{rT}_{3}$ did not affect $\left[{ }^{125} \mathrm{I}\right] \mathrm{T}_{3}$ uptake up to a concentration of $1 \mu \mathrm{M}$, but reduced $\left[{ }^{125} \mathrm{IT}_{3}\right.$ uptake by about $45 \%(P<0.05)$ at a concentration of $10 \mu \mathrm{M}$ (Fig. 5).

\section{Effects on TRH-induced TSH release}

Table 3 shows the effects of Tetrac and $\mathrm{rT}_{3}$ compared to those of Triac on TSH release during short term exposure to TRH. TSH release increased by approximately $90 \%$ after exposure to $100 \mathrm{nM}$ TRH for $2 \mathrm{~h}(P<0.05)$. This effect was significantly reduced by prcincubation $(2 \mathrm{~h}$ ) and incubation with Triac at a concentration as low as $0.01 \mathrm{~nm}(71 \%$ suppression; $P<0.05)$ and was fully blocked at concentrations of 1-10 nM Triac and higher $(P<0.05)$. Preincubation and incubation with Tetrac resulted in a dose-dependent inhibition that was significant at $1 \mathrm{nM}$, and a maximum $(82 \%$ inhibition; $P<0.05$ ) was seen with a concentration of $1 \mu \mathrm{M}$. Preincubation and incubation with $\mathrm{rT}_{3}$ showed a smaller inhibitory effect than that seen with Tetrac. Only at a $\mathrm{rT}_{3}$ concentration of $1 \mu \mathrm{M}$ was the TSH response to TRH significantly reduced $(57 \% ; P<0.05)$. A direct comparison between Tetrac and $\mathrm{T}_{4}$ in a single experiment showed that 100 nM Tetrac reduced TRH-induced TSH release to the same extent as $10 \mathrm{nM} \mathrm{T}_{4}$ (36\% and $27 \%$ inhibition, respectively; Table 4).

Similarly, the effects of preincubation and incubation with $3,3^{\prime}-T_{2}$ and $3,5-T_{2}$ were compared with those of $T_{3}$ (Table 5). The stimulation during short term exposure to $100 \mathrm{nM}$ TRH was $133 \%(P<0.05)$ in these experiments. Preincubation and incubation with $\mathrm{T}_{3}$ resulted in a dose-dependent inhibition of the TSH response to TRH, which was significant at concentrations of $1 \mathrm{nM}$ and higher. 3,5- $\mathrm{T}_{2}$ reduced the TSH response significantly at a dose of $1 \mathrm{nM}$, and the effect of $100 \mathrm{nM} 3,5-\mathrm{T}_{2}$ was as great as that of $1 \mathrm{nM} \mathrm{T}$ ( $55 \%$ suppression; $P<0.05)$. $3,3^{\prime}-T_{2}$ showed no inhibitory effect in doses less than $100 \mathrm{~nm}$, but this dose had the same effect as $100 \mathrm{nM} 3,5-\mathrm{T}_{2}$ or $1 \mathrm{nM} \mathrm{T}_{3}$.

\section{Serum binding and free fraction of Triac and Tetrac}

The binding of Triac and Tetrac to serum proteins was determined in four control subjects and four NTI patients (Table 6). In control subjects, Triac was equally bound to albumin and TBPA, but in NTI patients, more Triac was bound to albumin than to TBPA. Binding of Triac to TBG was negligible in both groups. In contrast, Tetrac was almost exclusively bound to TBPA in control subjects. Binding of Tetrac to albumin and TBG was about 5\%. Also, the binding of Tetrac to TBPA was reduced in NTI patients, whereas 
TABLE 1. Metabolism of $\left[{ }^{125} \mathrm{I}\right] \mathrm{T}_{3},\left[{ }^{125} \mathrm{I}\right] \mathrm{r} \mathrm{T}_{3}$, and $\left[{ }^{125} \mathrm{I}\right] \mathrm{T}_{4}$ in cultured anterior pituitary cells

\begin{tabular}{|c|c|c|c|c|c|c|}
\hline & \multicolumn{2}{|c|}{ Medium $(\%)$} & \multicolumn{4}{|c|}{ Cellular content (\%) } \\
\hline & Iodide & Conjugates & {$\left[{ }^{125} \mathrm{I}_{\mathrm{T}} \mathrm{T}_{3}\right.$} & {$\left[{ }^{125} \mathrm{I}\right] \mathrm{T}_{4}$} & {$\left[{ }^{125} \mathrm{I}\right] \mathrm{r} \mathrm{T}_{3}$} & {$\left[{ }^{125} \mathrm{I}\right] \mathrm{T}_{2}$} \\
\hline$\left[{ }^{125} \mathrm{I}\right] \mathrm{T}_{3}(3)$ & $0.0 \pm 0.0$ & $0.28 \pm 0.01$ & $98.0 \pm 0.1$ & & & \\
\hline$\left.\left[{ }^{125}\right]^{2}\right] \mathrm{T}_{4}(6)$ & $1.10 \pm 0.04$ & $0.16 \pm 0.01$ & $21.0 \pm 0.6$ & $71.2 \pm 0.3$ & & \\
\hline$\left[{ }^{125} \mathrm{I}_{\mathrm{T}}+100 \mu \mathrm{M}\right.$ PTU (3) & $1.89 \pm 0.03^{\alpha}$ & $0.16 \pm 0.0$ & $21.2 \pm 0.5$ & $70.9 \pm 0.9$ & & \\
\hline$\left[{ }^{125} \mathrm{I}\right] \mathrm{T}_{4}+1 \mu \mathrm{M} \mathrm{T} \mathrm{T}_{4}(3)$ & $0.44 \pm 0.09^{a}$ & $0.32 \pm 0.02^{a}$ & $1.9 \pm 0.3^{\alpha}$ & $88.1 \pm 1.8^{a}$ & & \\
\hline$\left[{ }^{125} \mathrm{I}_{\mathrm{r}} \mathrm{T}_{3}(3)\right.$ & $1.86 \pm 0.15$ & $2.12 \pm 0.02$ & & & $82.4 \pm 1.0$ & $6.3 \pm 0.6$ \\
\hline
\end{tabular}

Data represent the mean $\pm \mathrm{SE}$ of three to six observations in a single experiment as indicated in parentheses. Anterior pituitary cells were cultured for 3 days at a density of 500,000 cells/well. The cells were preincubated for 30 min in incubation medium containing $0.5 \%$ BSA. Then they were incubated for $24 \mathrm{~h}$ in the same medium containing $2 \times 10^{6} \mathrm{cpm}$ of any of the tracers without or with $100 \mu \mathrm{m}$ PTU or $1 \mu \mathrm{M} \mathrm{T}_{4}$. After incubation, aliquots of the medium and the cells were analyzed by Sephadex LH-20 chromatography. The iodothyronine fraction from the cells was further analyzed by HPLC.

${ }^{\alpha} P<0.001$ us. $\left[{ }^{125} \mathrm{I}\right] \mathrm{T}_{4}$ alone.

TABLE 2. Metabolism of $\left[{ }^{125} \mathrm{I}\right] \mathrm{T}_{4}$ and $\left\lceil^{125} \Pi\right\rceil$ Tetrac in cultured anterior pituitary cells

\begin{tabular}{cccc}
\hline Substrate & $\begin{array}{c}\text { Uplake } \\
\text { (\% dose) }\end{array}$ & \multicolumn{2}{c}{$\left[{ }^{125} \mathrm{~T}\right]$ activity in cells $(\%)$} \\
\hline $0.01 \% \mathrm{BSA}$ & & & \\
$\mathrm{T}_{4}$ or Tetrac & $\mathrm{T}_{3}$ or Triac \\
$\left.{ }^{125} \mathrm{H}\right] \mathrm{T}_{4}$ & $5.69 \pm 0.09$ & $85.2 \pm 0.8$ & $12.0 \pm 0.7$ \\
$\left.{ }^{125} \mathrm{I}\right] \mathrm{Tetrac}$ & $0.35 \pm 0.08$ & $74.5 \pm 3.6$ & $15.2 \pm 1.7$ \\
$0.1 \% \mathrm{BSA}^{1}$ & & & \\
$\left.{ }^{125} \mathrm{I}\right] \mathrm{T}_{4}$ & $2.03 \pm 0.07$ & $73.1 \pm 2.5$ & $17.8 \pm 1.2$ \\
$\left.{ }^{125} \mathrm{I}\right]$ Tetrac & $0.16 \pm 0.01$ & $79.4 \pm 4.2$ & $12.6 \pm 0.4$ \\
\hline
\end{tabular}

Data represent the mean $\pm \mathrm{SE}$ of three observations in a single experiment. Anterior pituitary cells were cultured for 3 days at a density of 500,000 cells/well. The experiment was performed as described in Table 2 with $\left.2 \times 10^{6} \mathrm{cpm} \mathrm{[}{ }^{125} \mathrm{I}\right] \mathrm{T}_{4}$ or $\left[{ }^{125} \mathrm{I}\right]$ Tetrac with BSA concentrations in the incubation medium as indicated. The product of $\left.{ }^{[25} \mathrm{I}\right] \mathrm{T}_{4}$ metabolism was identified by HPLC as $\mathrm{T}_{3}$, and that of $\left[{ }^{125} \mathrm{I}\right]$ Tetrac metabolism was identified as Triac.

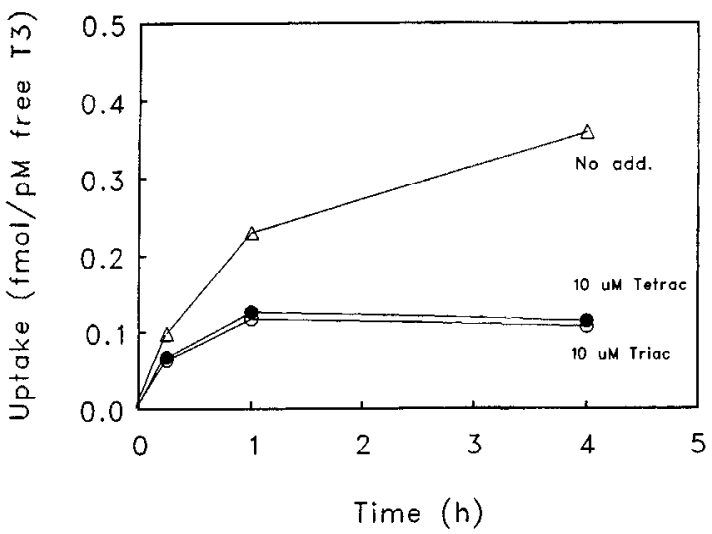

Fig. 4. Effects of unlabeled Triac or Tetrac on the uptake of $\left[{ }^{125} \mathrm{I}\right] \mathrm{T}_{3}$ in cultured anterior pituitary cells. Cells were cultured and the experiment was performed as described in Fig. 2, except that the incubation contained ${ }^{125} \mathrm{I}^{\mathrm{T}} \mathrm{T}_{3}(50,000 \mathrm{cpm})(\triangle)$ without or with $10 \mu \mathrm{M}$ Triac (O) or Tetrac ( ). Data represent the mean \pm SE of three to six observations from two independent experiments.

more Tetrac was bound to albumin than in the control subjects (Table 6).

The changes in serum binding during NTI (Table 6) resulted in remarkable changes in the free fractions of Triac and Tetrac in NTI patients (Fig. 6). In control subjects (no. 1-5), the free Triac fraction was approximately $0.04 \%$, whereas that of Tetrac was $0.0011 \%$. Similarly low values for the free fractions of Triac and Tetrac in normal serum have previously been described (27). During NTI (patients 6-11), the

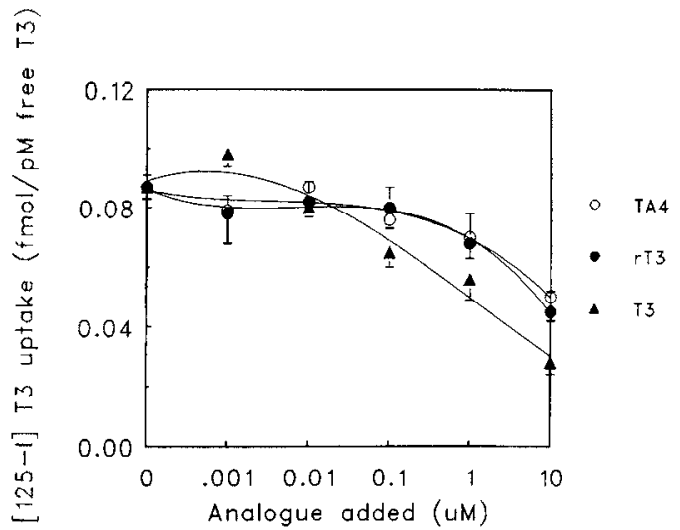

FIG. 5 Effects of unlabeled $\mathrm{T}_{3}(\Delta), \mathrm{rT}_{3}(\bullet)$, or Tetrac $\left(\mathrm{O} ; \mathrm{TA}_{4}\right)$ on the 15 -min uptake of $\left[{ }^{125} \mathrm{I}\right] \mathrm{T}_{3}$ in cultured anterior pituitary cells. Cells were cultured and uptake of $\left[{ }^{125} \mathrm{I}\right] \mathrm{T}_{3}$ was measured for $15 \mathrm{~min}$ as described in Fig. 2. Incubation was performed with $\left[{ }^{125} \mathrm{I}\right] \mathrm{T}_{3}(50,000$ $\mathrm{cpm}$ ) without or with unlabeled $\mathrm{T}_{3}, \mathrm{r}_{3} \mathrm{~T}_{3}$, or Tetrac present in concentrations of $1 \mathrm{nM}$ to $10 \mu \mathrm{M}$. Each point represents the mean $\pm \mathrm{SE}$ of six observations from two independent experiments.

free Triac fraction increased 2- to 8-fold, and that of Tetrac increased 2- to 12 -fold.

\section{Discussion}

The present study shows that both $\left[{ }^{125} \mathrm{I}\right]$ Tetrac and $\left[{ }^{125} \mathrm{I}\right] \mathbf{r} \mathrm{T}_{3}$ are taken up and metabolized in cultured anterior pituitary cells. In addition, Tetrac and its major metabolite Triac significantly reduced the TSH response to TRH at total hormone concentrations of 1 and $0.01 \mathrm{nM}$, respectively, whereas $\mathrm{rT}_{3}$ and its metabolite $3,3^{\prime}-\mathrm{T}_{2}$ had to be added at total concentrations of $1 \mu \mathrm{M}$ and $100 \mathrm{nM}$, respectively, to obtain a significant reduction of the TRH-induced TSH release.

Expressed as percent dose, the uptake of $\left[{ }^{125}\right.$ I]Tetrac and $\left[{ }^{125} \mathrm{~T}\right] \mathrm{r} \mathrm{T}_{3}$ was very low. That both tracers were taken up by pituitary cells was indicated by the 24-h incubation experiments. Around $15 \%$ of the cell-associated radioactivity was $\left[{ }^{125} \mathrm{I}\right]$ Triac after incubation with $\left[{ }^{125} \mathrm{I}\right]$ Tetrac, $6 \%$ of cell-associated radioactivity was $\left[{ }^{125} \mathrm{I}\right] \mathrm{T}_{2}$ after incubation with $\left[{ }^{125} \mathrm{I}_{\mathrm{r}} \mathrm{T}_{3}\right.$, and $15-20 \%$ of cell-associated radioactivity was $\left[{ }^{125} \mathrm{I}\right] \mathrm{T}_{3}$ after incubation with $\left[{ }^{125} \mathrm{I} \mathrm{T}_{4}\right.$. The deiodination of $\left[{ }^{125} \mathrm{ITT}_{4}\right.$ was almost completely blocked by simultaneous incubation with $1 \mu \mathrm{M}$ unlabeled $\mathrm{T}_{4}$, but not by $100 \mu \mathrm{M}$ PTU. $\left[{ }^{125} \mathrm{I}\right] \mathrm{T}_{3}$ was not metabolized in pituitary cells. Together, 
TABLE 3. Effects of Tetrac, $\mathrm{rT}_{3}$, and Triac on $\mathrm{TSH}$ release from anterior pituitary cells during short term exposure to TRH

\begin{tabular}{|c|c|c|}
\hline Exp conditions & $\begin{array}{c}\text { TSH release } \\
\text { (ng) }\end{array}$ & $\underset{(\%)}{\text { Stimulation }}$ \\
\hline $\begin{array}{l}\text { Controls (23) } \\
+100 \mathrm{nM} \text { TRH (25) }\end{array}$ & $\begin{array}{l}3.15 \pm 0.22 \\
5.95 \pm 0.14\end{array}$ & $+89^{a}$ \\
\hline $\begin{array}{l}\text { TRH + } 1 \mathrm{nM} \text { Tetrac }(3) \\
\text { TRH }+10 \mathrm{nM} \text { Tetrac }(6) \\
\text { TRH } 100 \mathrm{nM} \text { Tetrac }(3) \\
\text { TRH }+1 \mu \mathrm{M} \text { Tetrac }(9)\end{array}$ & $\begin{array}{l}4.87 \pm 0.26 \\
4.82 \pm 0.32 \\
4.09 \pm 0.39 \\
3.73 \pm 0.19\end{array}$ & $\begin{array}{l}+55^{b} \\
+53^{b} \\
130^{b} \\
+18^{b}\end{array}$ \\
\hline $\begin{array}{l}\mathrm{TRH}+1 \mathrm{nM} \mathrm{rT} \mathrm{r}_{3}(3) \\
\mathrm{TRH}+10 \mathrm{nM} \mathrm{rT}_{3}(6) \\
\mathrm{TRH}+100 \mathrm{nM} \mathrm{rT}_{3}(3) \\
\mathrm{TRH}+1 \mu \mathrm{MT}_{3}(6)\end{array}$ & $\begin{array}{l}5.22 \pm 0.64 \\
5.29 \pm 0.18 \\
4.93 \pm 0.43 \\
4.50 \pm 0.11\end{array}$ & $\begin{array}{l}+66 \\
+68 \\
+57 \\
+43^{b}\end{array}$ \\
\hline $\begin{array}{l}\text { TRH + } 0.01 \mathrm{nM} \text { Triac (3) } \\
\text { TRH }+0.1 \mathrm{nM} \text { Triac }(3) \\
\text { TRH }+1 \mathrm{nM} \text { Triac }(3) \\
\text { TRH }+10 \mathrm{~nm} \text { Triac }(9) \\
\text { TRH }+100 \mathrm{nM} \text { Triac }(6) \\
\text { TRH }+1 \mu \mathrm{M} \text { Triac }(6)\end{array}$ & $\begin{array}{l}4.06 \pm 0.35 \\
3.83 \pm 0.25 \\
3.40 \pm 0.26 \\
3.10 \pm 0.19 \\
3.43 \pm 0.26 \\
2.90 \pm 0.17\end{array}$ & $\begin{array}{r}+29^{b} \\
+22^{b} \\
+8^{b} \\
-2^{b} \\
+9^{b} \\
-8^{b}\end{array}$ \\
\hline
\end{tabular}

Data indicate the mean of four experiments, with the number of observations in parentheses. Each experiment included at least two of the tested compounds at comparable concentrations. Anterior pituitary cells were cultured for 3 days at a density of 500,000 cells/well. The cells were preincubated for $2 \mathrm{~h}$ in the absence or presence of Tetrac, $\mathrm{rT}_{3}$, or Triac at concentrations of $0.1 \mathrm{nM}$ to $1 \mu \mathrm{M}$. Then, they were incubated with TRH (100 nM) for $2 \mathrm{~h}$ without or with the additions indicated. TSH was measured by RIA.

${ }^{a} P<0.05$ us. controls.

${ }^{b} P<0.05$ vs. TRH alone.

TABLE 4. Comparison of the effects of Tetrac and $\mathrm{T}_{4}$ on TSH release during short term exposure to TRH

\begin{tabular}{|c|c|c|}
\hline Exp conditions & $\begin{array}{c}\text { TSH release } \\
\text { (ng) }\end{array}$ & $\begin{array}{c}\text { Stimulation } \\
(\%)\end{array}$ \\
\hline $\begin{array}{l}\text { Controls (6) } \\
+100 \mathrm{nM} \text { TRH (6) }\end{array}$ & $\begin{array}{l}2.50 \pm 0.49 \\
5.93+0.30\end{array}$ & $+137^{\alpha}$ \\
\hline $\begin{array}{l}\text { TRH + } 100 \text { nM Tetrac (3) } \\
\text { TRH + } 1 \mu \mathrm{M} \text { Tetrac }(3)\end{array}$ & $\begin{array}{l}4.09 \pm 0.39 \\
3.60 \pm 0.41\end{array}$ & $\begin{array}{l}+64^{b} \\
+44^{b}\end{array}$ \\
\hline $\begin{array}{l}\mathrm{TRH}+10 \mathrm{nM} \mathrm{T}_{4}(3) \\
\mathrm{TRH}+100 \mathrm{nM} \mathrm{T}_{4}(3)\end{array}$ & $\begin{array}{l}4.33 \pm 0.48 \\
4.30 \pm 0.19\end{array}$ & $\begin{array}{l}+73^{b} \\
+72^{b}\end{array}$ \\
\hline
\end{tabular}

Data indicate the mean $\pm \mathrm{SE}$ of three to six observations in a single experiment as indicated in parentheses. Anterior pituitary cells were cultured at a density of 500,000 cells/well. The experiment was performed as described in Table 3.

${ }^{a} P<0.05$ us. controls.

${ }^{b} P<0.05$ us. TRH alone.

these results indicated the presence of type II deiodinase activity in the cultured anterior pituitary cells (19).

Because of the low tracer uptake of $\left[{ }^{125} \mathrm{I}_{\mathrm{r}} \mathrm{T}_{3}\right.$ and $\left[{ }^{125} \mathrm{I}\right] \mathrm{Tet}-$ rac, it was impossible to test the effects of metabolic inhibitors and thyroid hormone analogs on the transport process. Therefore, we tested the effects of $r \mathrm{~T}_{3}$ and Tetrac on the uptake of $\left[{ }^{125} \mathrm{I}_{3} \mathrm{~T}_{3}\right.$. Neither $\mathrm{rT}_{3}$ nor Tetrac had an effect on the 15-min uptake of $\left[{ }^{125} \mathrm{I}\right] \mathrm{T}_{3}$ when added at concentrations of 1-100 nM, and both showed a significant reduction of $\left[{ }^{125} \mathrm{I}\right] \mathrm{T}_{3}$ uptake ( $45 \%)$ at a concentration of $1 \mu \mathrm{M}$. In a previous study, the presence of $10 \mu \mathrm{M} \mathrm{rT}$ reduced the 15-min uptake of $\left.{ }^{[25} \mathrm{I}\right] \mathrm{T}_{4}$ by $32 \%$, whereas $10 \mu \mathrm{M}$ Tetrac had no effect (23). As $\mathrm{T}_{3}$ and $\mathrm{T}_{4}$ probably share the same transport mechanism in
TABLE 5. Comparison of the effects of $3,3^{\prime}-T_{2}, 3,5-T_{2}$, and $T_{3}$ on TSH release from cultured anterior pituitary cells during short Lerm exposure to TRH

\begin{tabular}{|c|c|c|}
\hline Exp conditions & $\begin{array}{c}\text { TSH release } \\
\text { (ng) }\end{array}$ & $\underset{(\%)}{\text { Stimulation }}$ \\
\hline $\begin{array}{l}\text { Controls (21) } \\
+100 \mathrm{~nm} \text { TRH (21) }\end{array}$ & $\begin{array}{l}2.78 \pm 0.41 \\
6.48 \pm 0.45\end{array}$ & $+133^{a}$ \\
\hline $\begin{array}{l}\mathrm{TRH}+0.1 \mathrm{~nm} 3,3^{\prime}-\mathrm{T}_{2}(6) \\
\mathrm{TRH}+1 \mathrm{~nm} 3,3^{\prime}-\mathrm{T}_{2}(9) \\
\mathrm{TRH}+10 \mathrm{~nm} 3,3^{\prime}-\mathrm{T}_{2}(9) \\
\mathrm{TRH}+100 \mathrm{~nm} 3,3^{\prime}-\mathrm{T}_{2}(9)\end{array}$ & $\begin{array}{l}5.45 \pm 0.36 \\
4.84 \pm 0.43 \\
5.52 \pm 0.24 \\
3.98 \pm 0.29\end{array}$ & $\begin{array}{l}+96 \\
+74 \\
+98 \\
+43^{b}\end{array}$ \\
\hline $\begin{array}{l}\mathrm{TRH}+0.1 \mathrm{nM} \mathrm{T}_{3}(5) \\
\mathrm{TRH}+1 \mathrm{nM} \mathrm{T} \mathrm{T}_{3}(9) \\
\mathrm{TRH}+10 \mathrm{nM} \mathrm{T}_{3}(8) \\
\mathrm{TRH}+100 \mathrm{nM} \mathrm{T} \mathrm{T}_{3}(9)\end{array}$ & $\begin{array}{l}6.27 \pm 0.52 \\
4.04 \pm 0.52 \\
3.49 \pm 0.44 \\
3.10 \pm 0.26\end{array}$ & $\begin{array}{l}+125 \\
+45^{b} \\
+26^{b} \\
+12^{b}\end{array}$ \\
\hline $\begin{array}{l}\text { TRH + } 0.1 \mathrm{nM} 3,5-\mathrm{T}_{2}(6) \\
\text { TRH + } 1 \mathrm{nM} 3,5-\mathrm{T}_{2}(9) \\
\text { TRH + } 10 \mathrm{nM} 3,5-\mathrm{T}_{2}(9) \\
\text { TRH + } 100 \mathrm{nM} 3,5-\mathrm{T}_{2}(9)\end{array}$ & $\begin{array}{l}5.14 \pm 0.35 \\
4.52 \pm 0.28 \\
4.47 \pm 0.26 \\
4.03 \pm 0.36\end{array}$ & $\begin{array}{l}+85 \\
+63^{b} \\
+61^{b} \\
+45^{b}\end{array}$ \\
\hline
\end{tabular}

Data indicate the mean $\pm \mathrm{SE}$ of three experiments, with the number of observations in parentheses. Anterior pituitary cells were cultured at a density of 500,000 cells/well. Experiments were performed as described in Table 3.

${ }^{a} P<0.05$ us. controls.

${ }^{b} P<0.05$ us. TRH alone.

the pituitary $(23,28)$, one might expect that uptakes of $\mathrm{T}_{3}$ and $\mathrm{T}_{4}$ are equally inhibited by analogs.

The results obtained in the present and our previous study (23) do not argue against the possibility that $\mathrm{rT}_{3}$ is taken up by the same transporter involved with $\mathrm{T}_{3}$ and $\mathrm{T}_{4}$ uptake. The conclusion for Tetrac is more complicated. The uptake of Tetrac per picomolar concentration of free hormone $(\sim 1$ fmol) was as high as that of Triac (11). Furthermore, $10 \mu \mathrm{M}$ Tetrac reduced the uptake of $\left.{ }^{125} \mathrm{I}\right] \mathrm{T}_{3}(15 \mathrm{~min}$ to $4 \mathrm{~h})$ to the same extent as $10 \mu \mathrm{M}$ Triac. In our study of $\left[{ }^{125} \mathrm{I}\right]$ Triac uptake (11), it was concluded that at least part of Triac entered the pituitary by a mechanism different from the $\mathrm{T}_{3}$ transporter. Together, the similarities between Tetrac and Triac suggest that Tetrac enters the pituitary in the same way as Triac, i.e. at least partly by another mechanism than the $T_{3} / T_{4}$ transporter.

Tetrac was effective in reducing the TSH response to TRH at a total concentration of $1 \mathrm{nM}$, i.e. at a free concentration of 0.05 pM. $100 \mathrm{~nm}$ Tetrac showed the same inhibitory effect as $10 \mathrm{nM} \mathrm{T}_{4}$ or $0.01 \mathrm{~nm}$ Triac. Corrected for the difference in free fraction in medium with $0.5 \% \mathrm{BSA}$ (Tetrac, $0.005 \%$; $\mathrm{T}_{4}, 0.5 \%$; Triac, $0.5 \%), 5 \mathrm{pM}$ Tetrac was thus as effective as $50 \mathrm{pM} \mathrm{T}_{4}$ or 0.05 pM Triac. In a direct comparison between Triac and $T_{3}$, it was estimated that Triac was 8 times more effective than $\mathrm{T}_{3}$ in reducing the TSH response to TRH (11). Thus, the order of potency for reducing TSH release in pituitary cells seems to be Triac $>T_{3}>$ Tetrac $>T_{4}$.

The question remains of whether the effect of Tetrac or $\mathrm{T}_{4}$ on TSH release during $4 \mathrm{~h}$ of incubation is due to a direct effect or to an effect of their respective metabolites Triac and $\mathrm{T}_{3}$. In a previous study on the metabolism of $\left[{ }^{125} \mathrm{IJT}_{4}\right.$, it was found that iodide production into the medium after $6 \mathrm{~h}$ of incubation was about $40 \%$ of that found after $24 \mathrm{~h} \mathrm{(23).}$ Assuming a similar value for Tetrac, and that a proportion- 
TABLE 6. Distribution of Triac and Tetrac between serum proteins in control subjects and NTI patients

\begin{tabular}{|c|c|c|c|c|c|c|}
\hline \multirow{2}{*}{ Subject no. } & \multicolumn{3}{|c|}{ Triac (\%) } & \multicolumn{3}{|c|}{ Tetrac (\%) } \\
\hline & TBG & Albumin & TBPA & TBG & Albumin & TBPA \\
\hline Control 1 & 2.9 & 43.3 & 53.0 & 1.8 & 5.9 & 88.7 \\
\hline Control 2 & 0 & 49.9 & 48.6 & 2.4 & 6.1 & 89.2 \\
\hline Control 3 & 0 & 48.6 & 49.6 & 3.6 & 4.9 & 89.2 \\
\hline Control 4 & 0 & 45.5 & 53.3 & 7.7 & 5.6 & 85.6 \\
\hline Mean $\pm \mathrm{SE}$ & $0.7 \pm 0.7$ & $46.8 \pm 1.5$ & $51.1 \pm 1.2$ & $3.9 \pm 1.3$ & $5.6 \pm 0.3$ & $88.2 \pm 0.9$ \\
\hline NTI 7 & 0 & 59.0 & 39.7 & 3.0 & 6.2 & 89.2 \\
\hline NTI 8 & 0 & 54.1 & 44.8 & 4.3 & 9.2 & 85.7 \\
\hline NTI 9 & 1.0 & 68.6 & 29.7 & 2.6 & 10.5 & 83.2 \\
\hline NTI 11 & 2.0 & 64.3 & 33.3 & 3.8 & 10.5 & 81.2 \\
\hline Mean $\pm S E$ & $0.8 \pm 0.5$ & $61.5 \pm 3.2^{\alpha}$ & $36.9 \pm 3.4^{a}$ & $3.4 \pm 0.4$ & $9.1 \pm 1.0^{b}$ & $84.8 \pm 1.7$ \\
\hline
\end{tabular}

Data present individual values and the mean \pm SE of four healthy control subjects (no. 1-4) and four patients with NTI (no. 7-9, 11). The distribution of Triac and Tetrac among serum proteins was determined by agar gel electrophoresis.

${ }^{a} P<0.005$, NTI vs. control subjects.

${ }^{b} P<0.025$, NTI $v s$. control subjects.

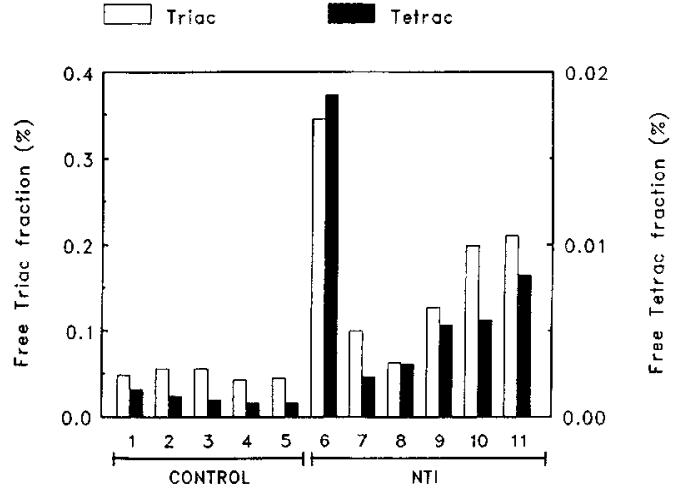

Fic. 6. Free fraction of Triac ( $\square$; left y-axis) and Tetrac ( $\mathbf{\square}$; right $\mathrm{y}$-axis) in serum obtained from five healthy control subjects (no. 1-5) and six patients with NTI (no.6-11). The free fractions were determined in duplicale by equilibrium analysis.

ally lower amount of $\left[{ }^{125} \mathrm{I}\right] \mathrm{T}$ riac is formed after $6 \mathrm{~h}$ of incubation ( $~ 5 \%$; i.e. $40 \%$ of $15 \%$ [ [25 I]Triac), this would mean that $10 \mathrm{~nm}$ Tetrac (in a volume of $0.5 \mathrm{ml}=5 \mathrm{pmol}$ ) with an uptake of $0.2 \%$ results in $0.5 \mathrm{fmol}$ intracellular Triac within $6 \mathrm{~h}$. Furthermore, $0.1 \mathrm{~nm}$ Triac (in a volume of $0.5 \mathrm{ml}=50$ fmol), with an uptake of $1 \%$ (11) would result in $0.5 \mathrm{fmol}$ intracellular Triac. As the effect of $10 \mathrm{~nm}$ Tetrac on TRHinduced TSH release was similar to that of $0.1 \mathrm{~nm}$ Triac, the effect of Tetrac on TRH-induced TSH release can be the result of its deiodination to Triac.

$\mathrm{rT}_{3}$ was only effective at a total concentration of $1 \mu \mathrm{M}$, whereas its metabolite $3,3^{\prime}-T_{2}$ induced a significant reduction in TRH-stimulated TSH release at a total concentration of 100 $\mathrm{nM}$. In contrast, the $\mathrm{T}_{3}$ metabolite $3,5-\mathrm{T}_{2}$, showed a significant effect on TSH release at a concentration of $1 \mathrm{nM}$ and was about 100 -fold less effective than $\mathrm{T}_{3}$. Thus, $3,5-\mathrm{T}_{2}$ seems to be more effective in reducing TSH release than $3,3^{\prime}-\mathrm{T}_{2}$, whereas the two diiodothyronines were equally effective in stimulation of the mitochondrial respiratory rate (16). However, our results support the in vivo observations in rats, in which 3,5- $\mathrm{T}_{2}$ reduced TSH secretion at doses 10- to 100-fold higher than those of $\mathrm{T}_{3}$ (18).

The question of whether $\mathrm{rT}_{3}$ or its metabolite $3,3^{\prime}-\mathrm{T}_{2}$ play a role in inhibition of TSH secretion during NTI can be addressed as follows: the normal total serum levels of $\mathrm{rT}_{3}$ and
$3,3^{\prime}-\mathrm{T}_{2}$ are 0.40 and $0.11 \mathrm{nM}(29)$. The same study showed that the serum total $r T_{3}$ concentration during NTI rose to $0.66 \mathrm{nM}$, whereas that of $3,3^{\prime}-\mathrm{I}_{2}$ declined to $0.05 \mathrm{~nm}$. This should be compared with the total hormone concentrations resulting in significant effects in vilro, i.e. $1 \mu \mathrm{Mr} \mathrm{r}_{3}$ and $100 \mathrm{nM} 3,3^{\prime}-\mathrm{T}_{2}$, respectively, in a medium containing $0.5 \% \mathrm{BSA}$ where the free fraction will be at least 10 -fold greater than that in serum. The difference between the effective concentrations in vitro and those present in vivo is thus at least a factor of 10,000 , which is not in favor of any biological significance of the two compounds in vivo. The small inhibitory effect of $\mathrm{rT}_{3}$ on TRH-induced TSH release cannot solely be explained by the low uptake of $\mathrm{rT}_{3}$ by pituitary cells; compared with $\mathrm{T}_{3}$, a 1000-fold higher total concentration of $\mathrm{rT}_{3}$ was required to reduce TSH release to the same extent $\left(1 \mu \mathrm{MrT} \mathrm{rT}_{3}\right.$ vs. $\left.1 \mathrm{nM} \mathrm{T}_{3}\right)$. In lerms of free concentration, the difference will be a factor of 500 (free $\mathrm{T}_{3}$ fraction, $3.8 \%$; free $\mathrm{rT}_{3}$ fraction, $1.9 \%$ ), whereas the difference in cellular uptake was a factor of 10 .

The normal total serum Tetrac concentration varies between $0.7 \mathrm{~nm}$ (15) and $1.3 \mathrm{~nm}$ (13). With a free fraction of $0.0011 \%$, the free Tetrac concentration in normal serum will be around $0.011 \mathrm{pm}$. As the production rate increases 2 -fold in fasting (15) and the mean free fraction increases 7-fold during NTI, the resulting free concentration during fasting or NTI will be about 0.15 pM. The lowest Tetrac concentration tested that reduced the response to TRH significantly was 1 $\mathrm{nM}$, i.e. a free Tetrac concentration of $0.05 \mathrm{pM}$, which is of same order of magnitude as the free concentrations occurring in vivo.

Just as postulated for Triac, the low serum Tetrac concentration may be the result of the very effective glucuronidation in the liver (30). Although the free concentration of Tetrac in serum (0.01-0.15 pM; see above) is lower than that of Triac (0.02-0.3 pM; estimated from Refs. 9, 11, and 31), $\mathrm{T}_{3}(2-4 \mathrm{pM})$ (3), or $\mathrm{T}_{4}(18-25 \mathrm{pm})(1-3)$, it is not excluded that Tetrac contributes to TSH suppression during NTI, because its uptake (per picomolar concentration of free hormone) into the pituitary is much larger than that of $T_{3}$ and $T_{4}$, whereas it is more effective than $\mathrm{T}_{4}$ in reducing the TSH response to TRH. Also, the tentative conclusion that Tetrac (and Triac) are at least partly taken up in the pituitary by other transport mech- 
anisms than $T_{3}$ and $T_{4}$ would support a possible role of the compound in vivo.

The large rise in the estimated free concentrations of Tetrac and Triac in patients with NTI is not only due to the increase in the production rate (possibly 2 - to 3 -fold) $(9,15)$, but also to the rise in free fraction (2- to 12-fold; this study). The latter seems due to the fact that the level of TBPA, the most important binding protein for the two compounds in serum, strongly decreases during illness (10).

The conclusion of our study is that Tetrac and $\mathrm{rT}_{3}$, the serum concentration of which increases during fasting and NTI, are taken up and metabolized in cultured anterior pituitary cells. Only Tetrac reduces the TSH response to TRH in vitro at concentrations comparable to those estimated in vivo. Because Tetrac probably enters the pituitary through another transport system such as that described for $T_{3}$ and $\mathrm{T}_{4}$, our results do not exclude a potential role for Tetrac in the inappropriately low serum ISH observed during NTI.

\section{Acknowledgments}

The material used in the TSH assay was kindly provided by the National Hormone and Pituitary Program of the NIDDK (Bethesda, MD). We thank P. M. van Koetsveld for expert assistance.

\section{References}

1. Spencer CA, Lum SMC, Wilber JF, Kaptein EM, Nicoloff JT 1983 Dynamics of serum thyrotropin and thyroid hormone changes in fasting. J Clin Endocrinol Metab 56:883-888

2. Wehmann RE, Gregerman RI, Burns WH, Saral S Santos GW 1985 Suppression of thyrotropin in the low thyroxine state of severe non-thyroidal illness. N Engl J Med 312:546-552

3. Van der Heyden JTM, Docter R, Van Toor H, Wilson JHP, Hennemann G, Krenning FP 1986 Effects of caloric deprivation on thyroid hormone tissue uptake and generation of $10 \mathrm{w}-\mathrm{T}_{3}$ syndrome. Am J Physiol 251:E156-E163

4. Docter R, Krenning EP, De Jong M, Hennemann G 1993 The sick euthyroid syndrome: changes in thyroid hormone serum parameters and hormone metabolism. Clin Endocrinol (Oxf) 39:499-518

5. Larsen PR 1982 Thyroid-pituitary interaction: feedback regulation of thyrotropin secretion by thyroid hormones N Engl J Med 306: 23-32

6. Lopresti JS, Mizuno L, Nimalysuria A, Anderson K, Spencer CA, Nicoloff JT 1991 Characteristics of 3,5,3'-triiodothyronine sulfate metabolism in euthyroid man. J Clin Endocrinol Metab 73:703-709

7. Spaulding SW, Smith TJ, Hinkle PM, Davis FB, Kung M-P, Roth JA 1992 Studies on the biological activity of triiodothyronine sulfate. J Clin Endocrinol Metab 74:1062-1067

8. Everts ME, Visser TJ, Van Buuren JCJ, Docter $R$, De Jong $M$, Krenning EP, Hennemann G 1994 Uptake of triiodothyronine sulfate and suppression of thyrotropin secretion in cultured anterior pituitary cells. Metabolism 43:1282-1286

9. LoPresti JS, Dlott RS 1992 Augmented conversion of $T_{3}$ to triac (T3AC) is the major regulator of the low $\mathrm{T}_{3}$ state in fasting man. Thyroid [Suppl 1] 2:S-94 (Abstract)

10. Carlin K, Carlin S 1993 Possible etiology for euthyroid sick syndrome. Med Hypotheses 40:38-43

11. Everts ME, Visser TJ, Moerings EPCM, Docter $\mathbf{R}$, Van Toor $\mathbf{H}_{\text {, }}$ Tempelaars AMP, De Jong M, Krenning EP, Hennemann G 1994 Uptake of triiodothyroacetic acid and its effect on thyrotropin secretion in cultured anterior pituitary cells. Endocrinology 135:27002707
12. Gershengorn M, Geras E, Marcus-Samuels BE, Rebecchi MJ 1979 Receptor affinity and biological potency of thyroid hormones in thyrotropic cells. Am J Physiol 237:E142-E146

13. Burger AG, Engler D, Sakoloff Staeheli V 1979 The effects of tetraiodothyroacetic and triiodothyroacetic acids on thyroid function in euthyroid and hyperthyroid subjects. Acta Endocrinol (Copenh) 92:455-467

14. Bracco D, Morin O, Schutz Y, Liang H, Jequier E, Burger AG 1993 Comparison of the metabolic and endocrine effects of $3,5,3^{\prime}$-triiodothyroacetic acid and thyroxine. J Clin Endocrinol Metab 77:221-228

15. Pittman CS, Shimizu T, Burger A, Chambers JB 1980 The nondeiodinative pathways of thyroxine metabolism: 3,5,3',5'-tetraiodothyroacetic acid turnover in normal and fasting human subjects. $\mathrm{J}$ Clin Endocrinol Metab 50:712-716

16. Lanni A, Moreno M, Cioffi M, Goglia F 1993 Effect of 3,3'di-iodothyronine and 3,5-di-iodothyronine on rat liver mitochondria. J Endocrinol 136:59-64

17. Horst C, Rokos H, Seitz HJ 1989 Rapid stimulation of hepatic oxygen consumption by 3,5-di-iodo-L-thyronine. Biochem J 261:945950

18. Horst C, Harneit A, Seitz HJ, Rokos H 1993 TSH suppression by 3,5-di-iodo-L-thyronine. J Endocrinol Invest [Suppl 2-6] 16:91 (Abstract)

19. Kohrle J, Hesch RD, Leonard JL 1991 Intracellular pathways of iodothyronine metabolism. In: Braverman LE, Utiger RD (eds) The Thyroid. Lippincott, Philadelphia, pp 144-189

20. Rutgers M, Heusdens FA, Visser TJ 1989 Metabolism of triiodothyroacetic acid $\left(\mathrm{TA}_{3}\right)$ in rat liver. $\mathrm{I}$. Deiodination of $\mathrm{TA}_{3}$ and $\mathrm{TA}_{3}$ sulfate by microsomes. Endocrinology 125:424-432

21. Oosterom R, Verleun T, Lamberts SWJ 1983 Basal and dopamineinhibited prolactin secretion by anterior pituitary cells: effects of culture conditions. Mol Cell Endocrinol 29:197-212

22. Everts ME, Docter R, Van Buuren JCJ, Van Koetsveld PM, Hofland LJ, De Jong M, Krenning EP, Hennemann G 1993 Evidence for carrier-mediated uptake of triiodothyronine in cultured anterior pituitary cells of euthyroid rats. Endocrinology 132:1278-1285

23. Everts ME, Docter R, Moerings EPCM, Van Koetsveld PM, Visser TJ, De Jong M, Krenning EP, Hennemann G 1994 Uptake of thyroxine in cultured anterior pituitary cells of euthyroid rats. Endocrinology 134:2490-2497

24. Docter R, Krenning EP, Bernard HF, Visser TJ, Hennemann G 1988 Inhibition of uptake of thyroid hormone into rat hepatocytes by preincubation with $N$-bromoacetyl-3,3',5-triiodothyronine. Endocrinology 123:1520-1525

25. Sterling K, Brenner MA 1966 Free thyroxine in human serum: simplified measurement with the aid of magnesium precipitation. J Clin Invest 45:153-163

26. Docter R, Bos G, Krenning EP, Fekkes D, Visser TJ, Hennemann G 1981 Inherited thyroxine excess: a serum abnormality due to an increased affinity for modified albumin. Clin Endocrinol (Oxf) 15: 363-371

27. Christensen LK 1960 The binding to serum proteins of acetic acid and propionic acid analogues of thyroxine and triiodothyronine. Endocrinology 67:407-412

28. Yan Z, Hinkle PM 1993 Saturable, stereospecific transport of 3,5,3'triiodo-L-thyronine an L-thyroxine into $\mathrm{GH}_{4} \mathrm{C}_{1}$ pituitary cells. J Biol Chem 268:20179-20184

29. Gavin LA, Hammond ME, Castle JN, Cavalieri RR 1978 3,3'Diiodothyronine production, a major pathway of peripheral iodothyronine metabolism in man. J Clin Invest 61:1276-1285

30. Moreno M, Kaptein E, Goglia F, Visser TJ 1994 Rapid glucuronidation of tri- and tetraiodothyroacetic acid to ester glucuronides in. human liver and to ether glucuronides in rat liver. Endocrinology 135:1004-1009

31. Gavin LA, Livermore BM, Cavalieri RR, Hammond ME, Castle JN 1980 Serum concentration, metabolic clearance, and production rates of 3,5,3'-triiodothyroacetic acid in normal and athyreotic man. $\mathrm{J}$ Clin Endocrinol Metab 51:529-534 